\title{
The Efforts to Improve IPS Teachers Abilities in Implementing Cooperative Learning Model Jigsaw Type Through Clinical Supervision
}

\author{
Dame Sihaloho \\ Education Administration Program \\ Postgraduate Program Universitas \\ Negeri Medan \\ J1. Willem Iskandar Psr V Medan,
} 20221

\author{
Benyamin Situmorang \\ State University of Medan \\ Postgraduate Program Universitas \\ Negeri Medan \\ Jl. Willem Iskandar Psr V Medan, \\ 20221
}

\author{
Yasaratodo Wau \\ Postgraduate Program Universitas \\ Negeri Medan \\ Jl. Willem Iskandar Psr V Medan,
}

20221

\begin{abstract}
The purpose of this study is to determine the improvement of the Social science (IPS) teachers abilityin implementing cooperative learning model jigsaw type through clinical supervision in Junior High School (SMP) Negeri Kecamatan Pancurbatu,Deli Serdang Regency.The subject of this research are five IPS teachers in SMP Negeri Kecamatan Pancurbatu, Deli Serdang Regency. The research focusing in IPS teachers abilities in arranging lesson plan and implementing cooperative learning model jigsaw type.The research design is school action research that was done in two cycles. Each cycle consist of four phases, those are planning, action, observation, and reflection.the research instrument used to collect data were research instrument lesson plans and research teacher observation sheet of capability in implementing cooperative learning model jigsaw type. The research results showed that in the first cycle the average value of the teachers ability in arranging lesson plan is in the category gold, and the average value of the teachers ability in implementing cooperative learning model jigsaw the teachers ability in arranging lessons plan is categorized very good, and the average value of the teachers ability in implementing cooperative learning model jigsaw type is categorized good.in conclusion, the result of the research showed that the using clinical supervision can improve IPS teachers abilities in implementing cooperative learning model jigsaw type in SMP Negeri Kecamatan Pancurbatu, Deli Serdang Regency.
\end{abstract}

Keywords - Cooperative; Jigsaw type; Clinical Supervision

\section{INTRODUCTION}

\section{PRELIMINARY}

Professional teachers are required to be able to display their skills as teachers in front of the class. The component that must be mastered is to use a variety of learning models that vary that can attract students 'and teachers' learning interests not only by giving lectures in front of the class. This means that the lecture method is not good, but at one time students become bored when only the teacher himself speaks, while students just sit still and listen. Boredom in listening to the teacher's description can turn off the spirit of student learning. Besides that there is a subject which is not appropriate to be conveyed through the lecture method and is more effective through other methods.

According to Ambarita, 'The improvement of teacher professionalism is the hope of every element of education'[1]. The professional teacher must have a habit of reading well. Because the rapid development of science brings rapid changes in human life. Teacher ability is a factor that influences the success of learning, teachers who have high abilities are creative and innovative and apply various learning models and new discoveries for classroom learning. Increasing the ability of teachers and the quality of learning in schools can be achieved through improving the quality of human resources (teachers and education personnel).

One of the competencies that must be mastered by a teacher is pedagogic competence. According to Sarimaya pedagogic competence is all the ability of teachers related to understanding students, designing and implementing learning, evaluating learning outcomes and developing students to actualize their potential. One element of the design and implementation of learning is the selection of learning models [2].

Based on data from the Ministry of Education and Culture's Directorate General of Teachers and Education Personnel in 2015 and 2016 the results of the Teacher competency test were still low, especially in Deli Serdang District. the average for professional competence is $39.67 \%$ which is still below the KKM set by the government, namely 5.50 and in 2016 for $61.08 \%$ of pedagogic competence and $65.03 \%$ of professional competence which is still below the established Minimum Passing Grade (KKM), namely 6, 50. From both the acquisition of pedagogic competency scores and teacher professional competence, both have not provided maximum results. 
The low UKG score based on the above data, especially Deli Serdang District, shows that teachers have not been able to fulfill the qualifications as competent teachers, especially pedagogic and professional competencies related to learning management, therefore the strategy and efforts of the government are needed to improve the ability of teachers to develop learning designs well .

One of the requirements that must be possessed by teachers in carrying out learning is the ability to apply learning models. The ability of a teacher to plan or choose and apply the right learning model when implementing learning for students has a role in improving learning outcomes, especially the achievement of learning goals in particular. According to Istarani the learning model is a whole series of presentation of teaching materials covering all aspects before, moderate and after learning conducted by the teacher and related facilities that are used directly or indirectly in the teaching and learning process [3].

One learning model that has been commonly used in teaching and learning is cooperative learning models. According to Hamruni cooperative learning model is a series of learning activities carried out by students in certain groups to achieve the learning objectives that have been formulated [4].

The diversity of types in cooperative learning provides opportunities for students to be interested in following the learning process so that boredom is removed. Mastering the cooperative learning model in the sense that the teacher understands, is able to explain and be able to apply it in learning to student participants. In the cooperative learning model there are several learning models where one of them is the Jigsaw type. Jigsaw cooperative learning is a learning model that is developed that encourages active students and helps each other in mastering the lesson to achieve maximum performance. Teaching and being taught by fellow students is an important part of the learning process. The selection of members in each group must also be considered for maximum learning. Group membership should be heterogeneous, both in terms of their abilities and other characteristics.

Based on the above opinion it can be concluded that jigsaw cooperative learning is learning with students learning in small groups consisting of 4-6 people, heterogeneous and working together to help each other. Each group member is responsible for completing part of the lesson material that must be learned and conveying the material to the original group members. Each group gets a bill for group discussion reports and is presented in front of the class.

Briefly this research can be described as follows, there are initial conditions namely learning without the Jigsaw model, then the first cycle supervision action is carried out; The teacher applies the Jigsaw model and the supervisor observes, and ends with conditions after observation. After the teacher has finished teaching, a feedback meeting is held to see and discuss the difficulties faced by the teacher. It needs to be maintained so that in this discussion, a free and friendly atmosphere is created between the teacher and supervisor so that the teacher is able to express the difficulties experienced. Next the teacher and the supervisor think of the possibility of improvements to be carried out in the next cycle. Based on the findings of the supervisor and the teacher made an agreement on a particular focus to be improved and improved by the teacher.

The research framework is as follows:

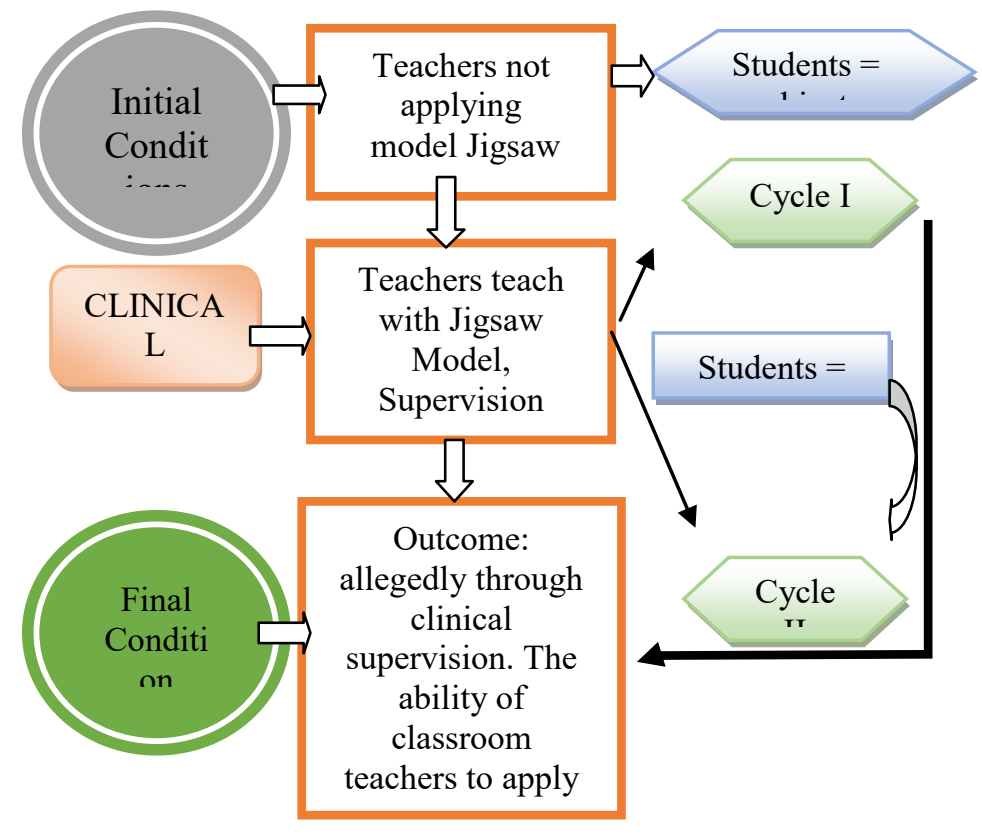

Fig 1. Thinking Framework Thinking

\section{RESEARCH METHODS}

This study uses qualitative research type of action (action research), to improve the ability of teachers to use the Jigsaw cooperative learning model. This action research was carried out in the form of a cycle and its implementation for two cycles. It is expected that the quality of learning increases if the teacher is able to do learning using the Jigsaw cooperative learning model

This research was conducted at Pancur Batu 1 Public Middle School which is located at Jalan Letjen Jamin Ginting No. 24 Pancur Batu and Pancur Batu 2 Public Middle School, having their address at Jalan Letjen Jamin Ginting No. 20 Pancur Batu in Deli Serdang Regency, North Sumatra Province. The subjects in this study were five teachers, consisting of two teachers who taught at Public Middle School 1 and three teachers who taught in State Junior High School 2 precisely in class VIII with social studies subjects at Pancur Batu Deli Serdang District.

The object of the research is the ability of the teacher to apply the Jigsaw cooperative learning model, to improve the teacher's ability, to be assisted through clinical supervision by the supervisor (school supervisor). The school supervisor acts as a supervisor and the researcher acts as an observer and facilitator. 
This research is said to be successful if the average value of the teacher's ability to use the Jigsaw learning model reaches a minimum of 80 and a minimum of $80 \%$ of the subjects can use the Jigsaw learning model. The value category is determined as follows: Score 91-100 (very good), 81-90 (good), 66-80 (enough), 56-65 (less), 0-55 (very less).

\section{RESEARCH RESULTS AND DISCUSSION}

Initial conditions that the teachers have not implemented the jigsaw cooperative learning model. After the socialization the teachers made lesson plans in accordance with the Jigsaw cooperative learning model. The results showed that initially the teacher did not have the ability to make preparation (RPP) Jigsaw cooperative learning models. The supervisor provides the opportunity for each teacher to revise the RPP. In the First Cycle researchers together with Supervisors make plans and prepare the things needed in the implementation of supervision, namely determining the supervision schedule, studying the observation instruments, preparing supporting facilities in the form of stationery, cameras, camcorders.

In the implementation action the Supervisor held a preliminary meeting (initial dialogue) with each teacher in a friendly, friendly, empathic atmosphere. The teacher realizes that the learning done so far is still teacher-centered, twoway communication between the teacher and the student, while communication between students is hardly implemented. Learning becomes less fun and even too boring. Supervisors and teachers review revised RPP. The result is that each teacher has increased the ability to make RPP with a jigsaw cooperative learning model that is the teacher is able to plan learning and overall the teacher successfully makes RPP well.

Based on observations made by supervisors and researchers, the score of the teacher's ability to apply the jigsaw cooperative learning model in the first cycle is as follows; two teachers in the less category with scores between $56-65$ and 3 teachers in the very poor category. While the average value of the overall ability of the teacher is 50 (very less).

Furthermore, the learning atmosphere and activities of students in participating in the Jigsaw learning model have not created a student learning atmosphere according to the jigsaw cooperative learning model with a score of 62.09 (less). With the details, there are three classes with a score of between 66-80 (enough) and two more classes belonging to the less category with a score of 56-65. The overall average score is 62.09 with less categories.

After further observation, reflection is done, by the supervisor and the teacher to analyze and discuss the results of the teacher's actions during the learning process. Some findings are that the teacher seems to try to make the best but still falls on the old pattern of teaching that is still teacher- centered, communication is still two-way, classrooms including student seating positions have not been arranged in such a way as to support interaction between students, still speaking method and question and answer, does not provide opportunities for students to ask questions. Only a few have applied the discussion method. Most teachers are nervous so they lose learning steps. Based on the entire process in the first cycle, it can be concluded that the teacher's ability to implement the Jigsaw cooperative learning model has not been successful. Therefore researchers, supervisors and teachers plan the second cycle of activities.

In the second cycle, the supervisor returns to meetings and dialogues with the teacher in a relaxed, intimate, humanitarian communication atmosphere to create good cooperation. The supervisor invites the teacher to recall the first cycle reflection points. These points are the main concerns of improvement in the second cycle. Based on observations made by third supervisors, researchers, and observers, the teacher's ability to apply Jigsaw learning models is as follows: four teachers score 91-100 (very good category) and one teacher gets a score between 81 to 90 (good category). The average score of all teachers is 94.45 (very good). Thus, the learning atmosphere and student activities following the Jigsaw learning model are as follows; on average the whole class managed to create a learning atmosphere of the jigsaw cooperative learning model with a score of 91.39 (very good) with details of two classes score between 91-100 (very good) and three classes with a score of 81-90 (good). The results of the reflection of the second cycle show an increase in the ability of teachers. The teacher seemed satisfied with the progress achieved and was grateful for this clinical supervision activity. Supervisors and researchers appreciate each teacher with all the effort made to obtain change/ improvement. In this second cycle the teachers looked ready both mentally and the learning media facilities used. Some teachers even use projectors as learning media that help the success of the second cycle. The supervisor invites the teacher not to stop there but continues to practice developing his professionalism as a certified teacher. The results of the study can be disclosed in the table below: 
TABLE 1 Recapitulation of Teacher's Ability Score to apply Jigsaw

\begin{tabular}{|c|c|c|c|c|c|c|c|c|}
\hline \multirow{3}{*}{ No } & \multirow{3}{*}{$\begin{array}{l}\text { Teacher } \\
\text { Name }\end{array}$} & \multicolumn{3}{|c|}{ Observer } & & & & \\
\hline & & \multicolumn{2}{|c|}{$\begin{array}{l}\text { CYCLE } \\
1\end{array}$} & \multirow{2}{*}{$\begin{array}{l}\text { Average } \\
\text { and } \\
\text { Value }\end{array}$} & \multicolumn{3}{|c|}{ CYCLE 2} & \multirow[t]{2}{*}{$\begin{array}{l}\text { Average } \\
\text { and Value }\end{array}$} \\
\hline & & P.1 & P. 2 & & P.1 & P. 2 & P.3 & \\
\hline 1 & Andi & 21 & 22 & $\begin{array}{l}21.5=59 \\
72\end{array}$ & 35 & 5 & 6 & $\begin{array}{l}35.33=98.1 \\
5\end{array}$ \\
\hline 2 & Sahat & 21 & 23 & $22=61.11$ & 34 & 5 & 2 & $\begin{array}{l}33.67=93.5 \\
2\end{array}$ \\
\hline 3 & Maruba & 12 & 14 & $13=36.11$ & 36 & 5 & 3 & $34.67=96.3$ \\
\hline 4 & Nesya & 9 & 13 & $11=30.56$ & 30 & 1 & 3 & $\begin{array}{l}31.33=87.0 \\
4\end{array}$ \\
\hline 5 & Santi & 20 & 25 & $\begin{array}{l}22.5=62 . \\
5\end{array}$ & 36 & 6 & 3 & $35=97.22$ \\
\hline
\end{tabular}

Cooperative Learning Model in Cycles 1 and 2

TABLE 2 Recapitulation of Student Activity Scores in following the Jigsaw Cooperative Model learning in Cycles 1 and 2

\begin{tabular}{|c|c|c|c|c|c|c|c|c|}
\hline \multirow{3}{*}{$\begin{array}{l}\mathrm{N} \\
\mathrm{o}\end{array}$} & \multirow{3}{*}{$\begin{array}{l}\text { Teache } \\
\text { r Name }\end{array}$} & \multirow{2}{*}{\multicolumn{6}{|c|}{\begin{tabular}{l|l} 
Observation Result \\
CYCLE
\end{tabular}}} & \multirow{3}{*}{$\begin{array}{l}\text { Averag } \\
\mathrm{e} \\
\text { Percen } \\
\text { tage }\end{array}$} \\
\hline & & \multicolumn{2}{|c|}{ CYCLE 1} & \multirow[b]{2}{*}{$\begin{array}{l}\text { Ave } \\
\text { rage } \\
\text { Per } \\
\text { cent } \\
\text { age }\end{array}$} & & & & \\
\hline & & .1 & P.2 & & P.1 & P. 2 & P.3 & \\
\hline & Andi & 66.67 & $\begin{array}{l}70.8 \\
3\end{array}$ & $\begin{array}{l}68.7 \\
5\end{array}$ & 91.67 & 87.5 & 91.67 & 90.28 \\
\hline & Sahat & 66.67 & $\begin{array}{l}66.6 \\
7\end{array}$ & $\begin{array}{l}66.6 \\
7\end{array}$ & 87.5 & 87.5 & 91.67 & 88.89 \\
\hline & $\begin{array}{l}\text { Marub } \\
\text { a }\end{array}$ & 54.17 & 62.5 & $\begin{array}{l}58.3 \\
4\end{array}$ & 95.83 & 95.83 & 95.83 & 95.83 \\
\hline & Nesya & 45.83 & $\begin{array}{l}54.1 \\
7\end{array}$ & 50 & 79.17 & 87.5 & 87.5 & 84.72 \\
\hline & Santi & 66.67 & $\begin{array}{l}66.6 \\
7\end{array}$ & $\begin{array}{l}66.6 \\
7\end{array}$ & 100 & 100 & 91.67 & 97.22 \\
\hline
\end{tabular}

\section{DISCUSSION}

This study provides an overview that the ability of social studies teachers to implement the Jigsaw cooperative learning model in Pancur Batu District Middle School can be improved through clinical supervision activities. Clinical supervision is applied as a series of collaborative guidance processes, aiming to assist teachers' professional development, behavioral changes teach teachers to a better level. The improvement that occurred was seen from several factors, starting from the ability of the teacher to prepare learning in the form of lesson plans in accordance with the Jigsaw model learning steps, which had increased. The RPP prepared by the teacher initially did not reflect the atmosphere of the Jigsaw cooperative learning model. This also shows that the learning done before supervision generally does not use the jigsaw cooperative learning model. Furthermore, when the teacher was given the opportunity to improve the lesson plan, the results of all teachers increased significantly.

Furthermore, the results of the first cycle supervision describe the ability of all teachers to implement Jigsaw learning models with very little score of 50 obtained, namely three teachers scored 56-65 (less category) and two teachers scored below 55 (poor category). The second cycle clinical supervision generally takes place very satisfactorily with an average score of 94.45. The teacher succeeded in implementing the jigsaw type of cooperative learning model, the method used was not limited to lectures and question and answer but was more varied and grouped so that the children were able to present the results of their group discussions. This action research shows that clinical supervision carried out in Pancur Batu District Middle School succeeded in improving the ability of classroom teachers to implement a jigsaw cooperative learning model. This research is supported by research conducted by Luh Amani, that the implementation of clinical supervision is able to improve the ability of teachers to manage the learning process [9]. Likewise, Rugaiyah's study developed information and technology-based clinical supervision guidelines to guide teachers to improve their teaching competencies. Student activity in the first cycle is only one class with an average score of 91.67, one class gets an average of 77.08 and the rest is under 70 [10]. While the average value of the overall student activity (10 classes) is 65 (less category ) Student activity in learning is in line with the teacher's ability to carry out learning with the Jigsaw model is still low. In the second cycle there was an increase; the learning atmosphere of students changes to be relaxed and fun, students are more active in the learning process, the opportunity for students to create and innovate openly. Students learn to communicate group findings through presentations, students dare to discuss, multi-way communication occurs, learning becomes effective. The results of this study are in line with Nurhayati's research which found that participation in learning and learning achievement of fifth grade students of SD Negeri Turi 1, Sleman in the field of Semester 1 Civics Study in 2013/2014 Academic Year can be increased through Active, Creative, Effective Learning and Fun [11]. The results of this study also support Astuti's findings in his research saying that there is an improvement in learning after clinical supervision [12].

\section{CONCLUSION}

1. The ability of social studies teachers to implement the jigsaw cooperative learning model can be improved in Pancur Batu District Middle School.

2. Clinical supervision with a collaborative approach can help social studies teachers improve their ability to apply Jigsaw cooperative learning models

3. The ability of social studies teachers to implement a jigsaw cooperative learning model can improve the quality of learning for students in Pancur Batu District Middle School.

\section{SUGGESTION}

1. For social studies teachers in Pancur Batu District Middle School to always improve the quality of learning by practicing continuously using learning models, especially the Jigsaw cooperative learning model

2. For supervisors and principals to implement clinical supervision as an effort to provide maximum service to teachers who are certified and those who have not so as 
to improve their professionalism in teaching and creating a fun and quality learning process.

\section{REFERENCES}

[1] Ambarita, Nasrun. 2016. Management of Education and Quality Improvement. Bandung; Alfabeta.

[2] Sarimaya, Farida. 2008. Teacher Certification, What, Why and How. Bandung: YramaWidya.

[3] Istarani, 2011. 58 Innovative Learning Models. Medan: Media Persada.

[4] 'Hamruni. 2012. Learning Strategy. Yogyakarta: Insan-Madani.

[5] Slavin, Robert.2009. Educational Psychology - Theories and Practices Translation by Marianto Samosir. Jakarta: Index

[6] Isjoni. 2009. Cooperative Learning. Bandung: Alfabeta.

[7] Ibrahim, M., Rachmadiarti, F., Nur, M., and Ismono. 2000. Cooperative Learning. Surabaya: University Press.

[8] Rusman. 2012. Learning Models. Bandung: Rajawali Perss.

[9] Amani, Luh, Anisa, 2013, Implementation of Clinical Supervision in Order to Improve the Ability of Teachers to Manage the Learning Process in Elementary Teachers of Group VII of Sawan Subdistrict, Journal of the University of Ganesha Postgraduate Program, Department of Primary Education, Volume 3

[10] Rugaiyah, 2016, Development of an Information and TechnologyBased Clinical Supervision Model, Journal of Educational Horizons, Th. XXXV, No. 3

[11]Nurhayati, 2016, Increasing Civics Learning Participation and Achievement with the PAKEM Model of Elementary School students, Journal of Primary School Research, Vol. 2 No.1

[12]Astuti, Ening Yuni Soleh, 2016, Increasing Teacher Professionalism through Clinical Supervision with Lesson Study Approach in Madrasah Tsanawiyah Bantul Kota, Journal of Madrasah Education, Vol. 1 Number 1 